\title{
Medicolegal Cases in An Urban City in South Southern Nigeria; A Hospital-Based Study
}

\author{
*Dr. Uchendu Obiorah Jude ${ }^{2}$ Dr. Nwafor Chukwuemeka Charles \\ ${ }^{3}$ Dr Eboreme O A, ${ }^{3}$ Dr Chukwuemeka Okoye \\ 1Department Of Pathology, Delta State University, Abraka, Delta State \\ 2Department Of Pathology, University Of Uyo, Uyo, Akwa Ibom State. \\ 3Central, Hospital, Benin City, Edo State, Nigeria \\ 4 Federal Medical Center, Asaba, Delta State, Nigeria. \\ Correspondence: Uchendu Jude Obiora
}

\begin{abstract}
Aims: To study medico legal cases in an urban health center in Nigeria.

Materials and Methods: This is a retrospective study of 8026 Medico legal cases seen in Casualty department of Central hospital, Benin City.

Results: Four thousand six hundred and four (57.35\%) cases were males and 3422(42.63\%) cases were females. Majority of cases were as a result of physical assault, road traffic accident and sexual violence (in descending order), and the peak age was the $3^{\text {rd }}$ decade.

Conclusion: The high proportion of physical assault related injuries as well the total hospital workload due to medicolegal cases is a public health concern and calls for action at level of hospital management and government at large.

Keyword: Medico legal. Physical assault, Injuries, Road traffic accident. Sexual assault.
\end{abstract}

\section{Introduction}

The word 'medico legal' is a compound word relating to both medicine and the law. Medico legal cases (MLC) refers to diseases or injuries where the consulting doctor after full evaluation, thinks that some investigations are required by the law enforcement agencies to establish responsibility of the culprit or claims of the victim / patient in line with the law of the country. ${ }^{1}$ These include physical assaults, road traffic accidents, sexual violence, domestic violence, occupational accidents, alcoholic intoxication, electrical injuries, poisoning, dog bites, snake bites, burns injuries, attempted suicide, cases of negligence by medical practitioners etc. ${ }^{1}$ While the primary role of the physician is to save life, he also has ethical and legal obligation of providing assistance to patients and the society in general in MLC. Vigilance and proper documentation while attending to MLC is instrumental in preventing grave consequences to the patient, the doctor or even the health institution in the court of law. ${ }^{2}$

Hospital-based study of such cases is important because it is may give insight into the value system and crime profile of the society. ${ }^{3}$ Results from such study will stimulate the government in making new laws or adopting some public health measures to reduce criminality or prevent such occurrence. ${ }^{3}$

\section{Materials And Method}

This is a retrospective study of all MLC that were seen in Casualty department of Central Hospital, Benin City from $1^{\text {st }}$ January 2012 to $31^{\text {st }}$ December 2014. Demographic data (sex and age), type of case and manner of causation were extracted from the medico legal register. Cases with insufficient information or of no medico legal significance were excluded from the study. These were subsequently analyzed using SPSS 21 and the results presented in tables and charts.

\section{Results}

During the period under study, a total of 8026 MLC were attended to in the casualty department of Central hospital, representing an average of 223 cases per month. Male cases $(\mathrm{n}=4604 ; 57.35 \%)$ outnumbered the female cases ( $\mathrm{n}=3422 ; 42.63 \%$ cases) and occurred in a ratio of $1.3: 1$ as shown in figure 1 . The 3 major causes of MLC were physical assaults, road traffic accidents (RTA) and sexual assaults which accounted for $68.03 \%, 17.28 \%, 10.23 \%$ of cases respectively as shown in table 1 . For males, most of the injuries were due to physical assaults $(41.07 \%)$, RTA (12.88\%) and gunshots (1.26\%). Among the females, physical assaults, sexual assaults and RTA were the commonest and accounted for $26.96 \%, 10.17 \%$ and $4.40 \%$ of cases respectively, as 
shown in table 1.Age group 21 -30 years closely followed by $31-40$ years accounted for most cases, $32.22 \%$ and $25.43 \%$ respectively, while 70 years and above accounted for the least number of cases $1.40 \%$. For both sexes, there was a steady rise in the age group involved, with the peak occurring in the $3^{\text {rd }}$ decade, followed by a steady decline after this, as shown in table 2.

The age distribution of cases in relation to the various modes of injuries is as shown in table 3 . The peak age for abortion, firearm injuries, physical assault, RTA, industrial accidents and those sustaining injury from fall from heights was the $3^{\text {rd }}$ decade. Majority $(50.67 \%)$ of the victims of sexual assault were in the age group of 11-20 years, followed by less than 10 years age group which accounted for $34.35 \%$ of sexual assault cases. Burns were mainly seen in age group 10 years and below $(48.37 \%)$. The clinical outcome is shown in table 4. Seventy three point four one percent of cases were managed on out -patient basis, while in the rest of cases, the victims were admitted for management. Fifty $(0.6 \%)$ of the cases were referred to tertiary centers because of the severity of the injury, while 131(1.63\%) of victims signed against medical advice on admission and left the hospital.

Figure 1: Sex distribution

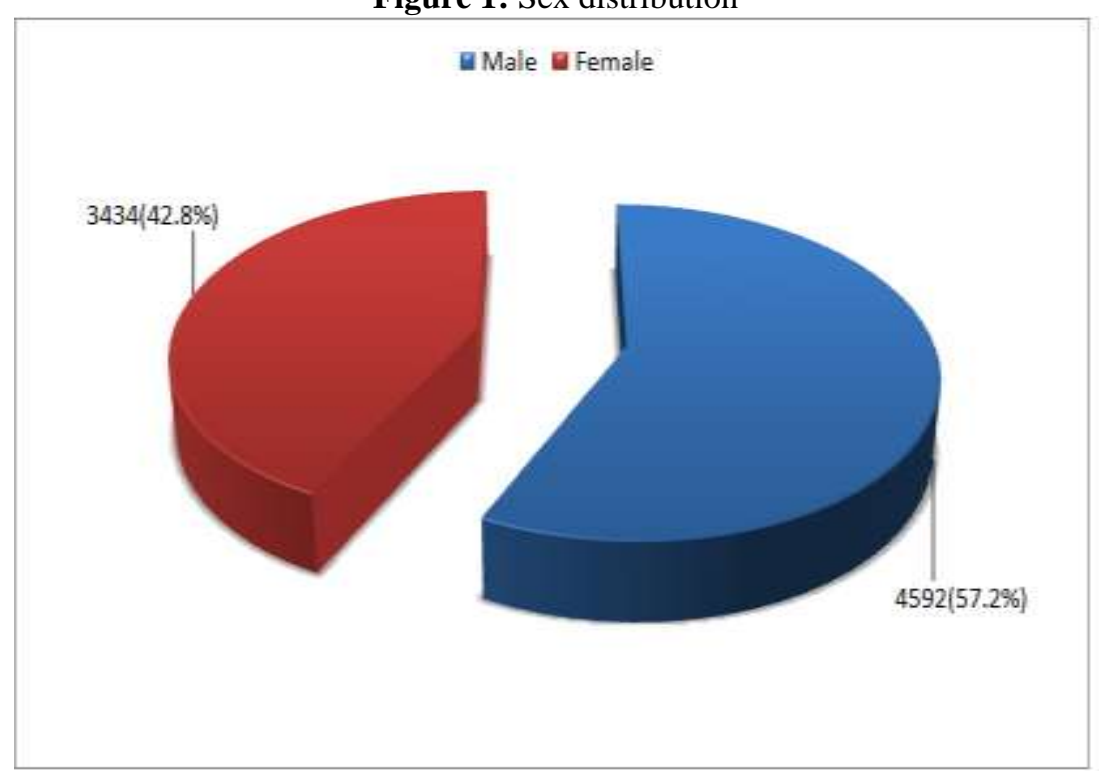

Table 1: Gender And Mode Of Injury Distribution

\begin{tabular}{llll}
\hline Mode of Injury & \multicolumn{1}{c}{ Gender } & Total \\
\hline Physical Assault & $3296(41.07)$ & $2164(26.96)$ & $5460(68.03)$ \\
RTA & $1034(12.88)$ & $353(4.40)$ & $1387(17.28)$ \\
Sexual assault & $5(0.06)$ & $816(10.17)$ & $821(10.23)$ \\
Burns & $89(1.11)$ & $64(0.80)$ & $153(1.91)$ \\
Gun shot & $101(1.26)$ & $6(0.59)$ & $107(1.33)$ \\
Fall from height & $33(0.41)$ & $8(0.10)$ & $41(0.51)$ \\
Dog bite & $8(0.10)$ & $10(0.13)$ & $18(0.22)$ \\
Industrial Accident & $13(0.16)$ & Nil & $13(0.16)$ \\
Domestic Accident & $11(0.14)$ & Nil & $11(0.14)$ \\
Abortion & Nil & $10(0.13)$ & $10(0.13)$ \\
Electrocution & $2(0.03)$ & Nil & $2(0.03)$ \\
Brought in dead & Nil & $2(0.03)$ & $2(0.03)$ \\
Attempted Suicide & Nil & $1(0.01)$ & $1(0.01)$ \\
\hline Total & $\mathbf{4 6 0 4 ( 5 7 . 3 6 )}$ & $\mathbf{3 4 2 2}(\mathbf{4 2 . 6 3})$ & $\mathbf{8 0 2 6}(\mathbf{1 0 0 . 0})$ \\
\hline
\end{tabular}

Table 2: Age Group And Sex Distribution Of Cases

\begin{tabular}{|c|c|c|c|}
\hline \multirow[t]{2}{*}{$\overline{\text { Age(years) }}$} & \multicolumn{2}{|c|}{ Sex } & \multirow[t]{2}{*}{ Total (\%) } \\
\hline & Male & Female & \\
\hline$\leq 10$ & $170(2.12)$ & $410(5.11)$ & $580(7.23)$ \\
\hline $11-20$ & $409(5.10)$ & $712(8.87)$ & 1121(13.97) \\
\hline $21-30$ & $1577(19.65)$ & $990(12.34)$ & $2569(32.00)$ \\
\hline $31-40$ & $1336(16.65)$ & $705(8.78)$ & $2041(25.43)$ \\
\hline $41-50$ & $605(7.54)$ & $294(3.66)$ & $899(11.20)$ \\
\hline $51-60$ & $314(3.89)$ & $182(2.27)$ & $496(6.18)$ \\
\hline $61-70$ & $132(1.65)$ & $76(0.95)$ & $208(2.59)$ \\
\hline$>70$ & $59(0.74)$ & $53(0.66)$ & $112(1.40)$ \\
\hline Total & 4604(57.2) & $3422(42.8)$ & $8026(100.0)$ \\
\hline
\end{tabular}




$$
\chi^{2}=502.039 \quad \mathrm{df}=7 \quad \mathrm{p}<0.001
$$

\begin{tabular}{|c|c|c|c|c|c|c|c|c|c|}
\hline \multirow{2}{*}{$\begin{array}{l}\text { Mode of } \\
\text { Injury }\end{array}$} & \multicolumn{8}{|c|}{ Age Group (\%) } & \multirow[b]{2}{*}{ Total } \\
\hline & $\square \mathbf{1 0}$ & $11-20$ & $21-30$ & $31-40$ & $41-50$ & $51-60$ & 61-70 & $>70$ & \\
\hline Abortion & Nil & $4(40)$ & $5(50)$ & $1(10)$ & Nil & Nil & Nil & Nil & $10(100)$ \\
\hline $\begin{array}{l}\text { Attempted } \\
\text { Suicide }\end{array}$ & Nil & $1(100)$ & Nil & Nil & Nil & Nil & Nil & Nil & 1(100) \\
\hline Burns & $\begin{array}{c}74(48 . \\
37)\end{array}$ & $\begin{array}{c}21(13 . \\
73)\end{array}$ & $\begin{array}{c}22(14.38 \\
)\end{array}$ & $\begin{array}{c}16(10.46 \\
)\end{array}$ & $12(7.84)$ & $4(2.61)$ & $1(0.65)$ & $3(1.96)$ & $\begin{array}{l}153(10 \\
0)\end{array}$ \\
\hline Dog bite & $\begin{array}{c}4(22.2 \\
2)\end{array}$ & $\begin{array}{c}2(11.1 \\
1)\end{array}$ & $5(27.78)$ & $2(11.11)$ & $4(22.22)$ & Nil & $1(5.56)$ & Nil & $18(100)$ \\
\hline $\begin{array}{l}\text { Domestic } \\
\text { Accident }\end{array}$ & $\begin{array}{c}3(27.2 \\
7)\end{array}$ & $\begin{array}{c}\text { 1(9.09 } \\
\text { ( }\end{array}$ & $3(27.27)$ & $2(18.18)$ & $2(18.18)$ & Nil & Nil & Nil & 11(100) \\
\hline Electrocution & Nil & Nil & Nil & $2(100)$ & Nil & Nil & Nil & Nil & $2(100)$ \\
\hline $\begin{array}{c}\text { Fall from } \\
\text { height }\end{array}$ & $\begin{array}{c}9(21.9 \\
5)\end{array}$ & $\begin{array}{c}8(19.5 \\
1)\end{array}$ & $\begin{array}{c}11(26.83 \\
)\end{array}$ & $3(7.32)$ & $14(34.15)$ & $2(4.88)$ & $2(4.88)$ & $2(4.88)$ & 41(100) \\
\hline Gun shot & $1(0.93)$ & $\begin{array}{c}6(5.61 \\
)\end{array}$ & $\begin{array}{c}51(47.66 \\
)\end{array}$ & $\begin{array}{c}27(25.23 \\
)\end{array}$ & $\begin{array}{c}13(12.15 \\
)\end{array}$ & $7(6.54)$ & $2(1.87)$ & Nil & $\begin{array}{c}107(10 \\
0)\end{array}$ \\
\hline $\begin{array}{l}\text { Industrial } \\
\text { Accident }\end{array}$ & Nil & Nil & $5(38.46)$ & $3(23.08)$ & $2(15.38)$ & $3(23.08)$ & Nil & Nil & $13(100)$ \\
\hline $\begin{array}{l}\text { Physical } \\
\text { Assault }\end{array}$ & $\begin{array}{c}81(1.4 \\
8)\end{array}$ & $\begin{array}{c}538(9 . \\
85)\end{array}$ & $\begin{array}{c}1946 \\
(35.64)\end{array}$ & $\begin{array}{c}1592 \\
(29.16)\end{array}$ & $\begin{array}{c}705(12.9 \\
1)\end{array}$ & $\begin{array}{c}369(6.76 \\
)\end{array}$ & $147(2.69)$ & $\begin{array}{c}82(1.50 \\
)\end{array}$ & $\begin{array}{l}5460 \\
(100)\end{array}$ \\
\hline RTA & $\begin{array}{c}122(8 . \\
80)\end{array}$ & $\begin{array}{c}124(8 . \\
94)\end{array}$ & $\begin{array}{c}435(31.3 \\
6)\end{array}$ & $\begin{array}{c}370(26.6 \\
8)\end{array}$ & $\begin{array}{c}149(10.7 \\
4)\end{array}$ & $\begin{array}{c}107(7.71 \\
)\end{array}$ & $53(3.82)$ & $\begin{array}{c}23(1.66 \\
)\end{array}$ & $\begin{array}{l}1387 \\
(100)\end{array}$ \\
\hline Sexual assault & $\begin{array}{c}282(34 \\
.35)\end{array}$ & $\begin{array}{c}416(50 \\
.67)\end{array}$ & $\begin{array}{c}86(10.48 \\
)\end{array}$ & $23(2.80)$ & $8(0.97)^{\prime}$ & $4(0.49)$ & $1(0.12)$ & $1(0.12)$ & 821 \\
\hline $\begin{array}{c}\text { Brought in } \\
\text { dead }\end{array}$ & Nil & Nil & Nil & Nil & Nil & Nil & $1(50)$ & $1(50)$ & $2(100)$ \\
\hline Total (\%) & $\begin{array}{c}580 \\
(7.23)\end{array}$ & $\begin{array}{c}1121 \\
(13.97 \\
)\end{array}$ & $\begin{array}{c}2569 \\
(32.00)\end{array}$ & $\begin{array}{c}2041 \\
(25.43)\end{array}$ & $\begin{array}{c}899 \\
(11.20)\end{array}$ & $\begin{array}{c}496 \\
(6.18)\end{array}$ & $\begin{array}{c}208 \\
(2.59)\end{array}$ & $\begin{array}{c}112 \\
(1.40)\end{array}$ & 8026 \\
\hline
\end{tabular}

Table 3: Age Group Distribution Of Cases In Relation To Mode Of Injury

Table 4: Clinical Outcome Of Medico Legal Cases

\begin{tabular}{|c|c|c|c|c|}
\hline \multirow[t]{2}{*}{ MODE OF INJURIES } & \multicolumn{4}{|c|}{ Outcome in Casualty department } \\
\hline & Outpatient & Admitted & SAMA & Referred \\
\hline Abortion & $4(40.00 .0)$ & $6(60.00)$ & Nil & Nil \\
\hline Attempted Suicide & Nil & $1(100.00)$ & Nil & Nil \\
\hline Burns & $8(15.09)$ & $130(84.97)$ & $15(9.80)$ & Nil \\
\hline Dog bite & $16(88.9)$ & $2(11.1)$ & Nil & Nil \\
\hline Domestic Accident & Nil & $8(72.72)$ & $3(27.27)$ & Nil \\
\hline Electrocution & Nil & $2(100.0)$ & Nil & Nil \\
\hline Fall from height & $5(12.20)$ & $36(87.81)$ & Nil & Nil \\
\hline Gun shot & $14(13.08)$ & $93(86.92)$ & Nil & Nil \\
\hline Industrial Accident & Nil & $13(100.0)$ & Nil & Nil \\
\hline Physical Assault & 4852(88.9) & $589(10.20)$ & $19(0.35)$ & Nil \\
\hline RTA & 183(13.19) & $1138(82.05)$ & $16(1.15)$ & $50(3.61)$ \\
\hline Sexual assault & $808(98.42)$ & $12(1.46)$ & $1(0.12)$ & Nil \\
\hline brought in dead & $2(100.0)$ & $\mathrm{Nil} \%$ & Nil & Nil \\
\hline Total & $5892(73.41)$ & $2030(25.29)$ & 131(1.63) & $50(0.62)$ \\
\hline
\end{tabular}

$\chi^{2}=4499.972$ df $=65 \quad \mathrm{p}<0.001$

$\mathrm{SAMA}=$ Signed against medical advice

\section{Discussion}

The present study showed that male cases $(57.36 \%)$ slightly outnumbered the female cases $(43.64 \%)$. The discrepancy is relatively small when compared to the overwhelming male predominance reported by Saxena et al, ${ }^{4}$ Yatoo et al, ${ }^{5}$ Paranitharan et al, ${ }^{6}$ Dileep Kumar et al, $^{7}$ and Siddap et al $^{8}$ where male cases accounted for $81.44 \%, 74.03 \%, 73.3 \%$ and $71.76 \%$ of MLC respectively. This discrepancy may be due to different study environments and their behavior patterns, since the previous studies were conducted in India and 
Sri Lanka. Our observation may reflect a changing role of the female gender in the urban society with more women being involved in breadwinning role and outdoor activities; and therefore increasing rate of exposure to different forms of injuries. The present harsh economic reality, high cost of livelihood and high unemployment rate especially among male gender, women empowerment, marriage instability and declining marriage rate as well an erosion of traditional African value system may be responsible for the relatively high rate of women involvement in outdoor activities as seen in this study. ${ }^{9,10,11}$

In the index study, the highest number of cases were observed in the age range of 21-30 years. This is in keeping with reports by Saxena et al, ${ }^{4}$ Yatoo et al, ${ }^{5}$ Paranitharan et al,${ }^{6}$ Dileep Kumar et al,${ }^{7}$ and Siddap et al ${ }^{8}$ and can be attributed to the activity-prone nature of this age group and therefore the greater likelihood of their involvement in outdoor activities with consequent increased risk of injuries.

Majority of injuries $(68.03 \%)$ resulted from physical assault which is a far cry from earlier reports by Saxena et al, ${ }^{4}$ Yatoo et al, ${ }^{5}$ Paranitharan et al, ${ }^{6}$ Dileep Kumar et al, ${ }^{7}$ and Siddap et al ${ }^{8}$ all of which indicted RTA as the most common culprit. The predominance of physical assaults in our society as observed is a serious demographic earthquake and calls for urgent attention by all stakeholders. It is a pointer to a breakdown of law and order, increasing rate of cultism, violence, jungle justice and criminality, as well as a loss of faith in the country's justice system. Interpersonal relationship / conflict resolution should be included in primary and secondary school curriculum, so that individuals will be taught early in life to be less confrontational in their daily activities. WHO has described Nigeria one of the most dangerous countries in the world because of the outrageous statistics arising from RTA. ${ }^{12,13}$ Causes include poor road network, traffic overload, the laxity of the law enforcement agencies and reckless driving to mention a few. ${ }^{14}$ RTA took a distant second position in the index study. This is a tip of the iceberg as the methodology used in this study excluded on-the-spot deaths and more fatal cases that were preferentially rushed to more sophisticated health centers.

Sexual assault rank third among the medico- legal cases in our study, with majority of victims being females within the vulnerable age range 11-20 years. Younger females $(<10$ years) were also not spared. This is consistent with earlier report by Uchendu et al. ${ }^{15}$ The complications that follow this assault is enormous and include pregnancy, sexual transmissible diseases, and various grades of physical and psychological traumas. ${ }^{15}$

An average of 223 cases with 56 new cases requiring admission every month is a great burden to a secondary healthcare facility. Besides the economic cost to the individuals and families concerned, the number of productive hours lost by the victims is a serious public health concern. Majority of burns and gunshot injury patients were admitted for proper management, there is need for upgrading of the facilities and the man power in general and plastic surgery units, since these 2 units manage most of the admitted cases.

The major limitations of this study are its retrospective nature, lack of mention of the day of the week and time when these MLC occurred. Lack of information about educational status of victims and type of job they do, if they are working and characterization of the assailants. If they above listed variables were known, it would have helped in better understanding of these MLC. Though not evaluated in this study, the loss of lives in relation to these cases increases the gravity of the problems. Public health awareness and education, strict enforcement of law and order and government policies are vital tools towards reversing this trend. In conclusion, this study showed that physical assault, RTA and sexual violence account for majority of medico legal cases. Males are affected more than females and the peak age is in the $3^{\text {rd }}$ decade of life. The high burden on this secondary health facility is a major concern. There is need to train hospital staff including medical officers in casualty department on appropriate handling of medico legal cases.

\section{Limitations Of The Data}

Documentation of patient's information are scanty, making it difficult to extract relevant information for this study. Our study is therefore limited to the information that could be retrieved during the study.

\section{Reference}

[1]. Dogra T D, Rudra A. Lyon's Medical Jurisprudence \& Toxicology. 11th Ed. Delhi Law House. $2007: 367$.

[2]. Raj V M, Vasudeva D S, Gagan S. Guidelines for Handling Medico Legal Cases. International Journal of Health Information and Medical Research 2014; 1(1):2-5.

[3]. Yogendra M, Chawla R, Sharma G, Malik P, Singh R, Tripathi A. Profile of medico legal cases in causality of a rural medical college of Hariyana. Journal of Indian Academy of Forensic Medicine 2013; 35(4): 367-8.

[4]. Saxena A, Kumar V, Chaudhary V S R, Singh J, Awasthi S. Pattern of Medico-legal Cases in the Casualty Department of A Teaching Hospital, Bareilly, Uttar-Pradesh.. J Indian Acad Forensic Med. 2015; 37 (4): 339-341.

[5]. Yatoo GH, Jalali S, Malik A, Khan A. Profile and pattern of Medico legal cases attending tertiary care hospital in North India. IJMPS 2015; 5(5):1-8.

[6]. Paranitharan P1, Perera W N S, Rajapaksha W R A S, Perera W P P. A prospective study on clinical forensic cases examined at North Colomb Teaching hospital; New challenges for the 21 st century. Sri Lanka Journal of Forensic Medicine, Science \& Law 2015;(2):18-23.

[7]. Dileep Kumar R, Siddaramanna T C, Shailesh V Parate, Hemanthraj M N. Retrospective Study of Profile of Medico-legal Cases in Tumkur Region, Karnataka. IJBAR 2015; 6(04): 339-340. 
[8]. Siddappal S C, Datta A. Medico-legal Cases treated at a Tertiary Care Hospital in Central Karnataka" Indian Journal of Forensic and Community Medicine 2015; 2(4):193-197.

[9]. Amadi Ugochukwu P N. Maritial Crisis in the Nigerian Society: Causes, Consequences and Management Strategies. MJSS 2014; 5(26): 133-138.

[10]. Asaju K, Arome S, Anyio A F. The rising rate of unemployment in Nigeria: the socio-economic and political implications. Global Business and Economics Research Journal 2014; 3(2):12-16.

[11]. Eboiyehi F A, Muoghalu C O, Bankole A O. In the husbands' shoes: Feminism and political economy of women breadwinners in Ile-Ife, southwestern Nigeria. Journal of International Women's Studies 2016; 17(4): 102-121.

[12]. WHO, 2004. World Report on Road Traffic Injury Prevention: Summary. World Health Organization, Geneva, Switzerland.

[13]. WHO 2013 report on Accidents in Africa.

[14]. Ohakwe J, Iwueze I S, Chikezie D C. Analysis of Road Traffic Accidents in Nigeria: A Case Study of Obinze/Nekede/Iheagwa Road in Imo State, Southeastern, Nigeria. Asian Journal of Applied Sciences 2011;4: 166-175.

[15]. Uchendu O J, Igbe A P. Sexual Assault in Benin City, Nigeria, a Silent Epidemic. Indian Journal of Forensic Medicine \& Toxicology 2015; 9:28-32. 